
RESEARCH AND DEVELOPMENT

\author{
http://journal.unnes.ac.id/sju/index.php/higeia
}

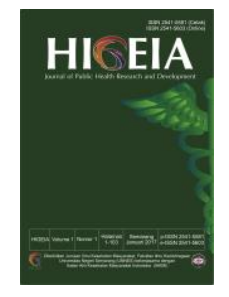

\title{
KEJADIAN TUBERKULOSIS MULTI DRUG RESISTANT DI RSUP Dr. KARIADI
}

\section{Devi Triandari*, Sri Ratna Rahayu}

Administrasi Kebijakan Kesehatan, Jurusan Ilmu Kesehatan Masyarakat, Fakultas Ilmu Keolahragaan, Universitas Negeri Semarang

\section{Info Artikel}

Sejarah Artikel:

Diterima Februari 2018

Disetujui Maret 2018

Dipublikasikan April 2018

\section{Keywords:}

WISN Methode, Workload, Sanitation Clinical

\begin{abstract}
Abstrak
Indonesia menduduki rangking ke 8 dari 27 negara dengan beban tinggi prioritas Tuberculosis Multi Drug Resistant (TB MDR). Tuberkulosis MDR di RSUP Dr. Kariadi mengalami kenaikan selama 3 tahun terakhir. Tahun 2014 sebanyak 688 kasus, tahun 2015 hingga 1.183 kasus, tahun 2016 mencapai 1.442 kasus, hingga Mei tahun 2017 sebanyak 2.061 kasus. Tujuan penelitian untuk menganalisis faktor yang berhubungan dengan kejadian TB MDR pada RSUP. Dr. Kariadi Kota Semarang. Jenis penelitian merupakan observasional analitik dengan rancangan case control. Sampel penelitian yaitu 72 kasus dan 72 kontrol dengan teknik purposive sampling. Data dianalisis secara univariat dan bivariat (dengan uji chi square) dengan SPSS. Hasil menunjukkan bahwa hasil pengobatan TB $(\mathrm{OR}=5,64 ; 95 \% \mathrm{CI}=2,23-14,23)$, kepatuhan minum obat $(\mathrm{OR}=2,49 ; 95 \% \mathrm{CI}=1,17$ $5,28)$, peran aktif $\mathrm{PMO}(\mathrm{OR}=2,37 ; 95 \% \mathrm{CI}=1,14-4,89)$ berhubungan dengan kejadian TB MDR di RSUP. Dr. Kariadi Kota Semarang. Sedangkan jenis kelamin $(\mathrm{OR}=1,25 ; 95 \% \mathrm{CI}=0,65-2,41)$ dan tingkat pendidikan $(\mathrm{OR}=1,48 ; 95 \% \mathrm{CI}=0,77-2,85)$ tidak berhubungan dengan kejadian TB MDR di RSUP. Dr. Kariadi Kota Semarang. Faktor yang paling dominan dengan kejadian TB MDR adalah hasil pengobatan TB.
\end{abstract}

\section{Abstract}

Indonesia ranks $8^{\text {th }}$ out of 27 countries with high priority burden of MDR Tuberculosis. MDR Tuberculosis at dr. Kariadi Hospital has increased over the last 3 years. In 2014 there were 688 cases, 2015 there were 1,183 cases, 2014 reached 1442 cases, until May 2017 reached 2,061 cases. The purpose of this study was to analyze factors related to MDR TB incidence at Dr. Kariadi Hospital. This research was analytic observational case control design. The samples were 72 cases and 72 controls by purposive sampling technique. Data were analyzed univariate and bivariate (chi square test) with SPSS. The results show that the active role of medicine swallowed keeper $(O R=2.37 ; 95 \% C I=1.14-4.89)$, result of $T B$ treatment $(O R=5.64 ; 95 \% C I=2.23$ 14,23), and medication adherence $(O R=2.49 ; 95 \% C I=1.17-5.28)$ was associated with $M D R T B$ incidence at the Dr. Kariadi Hospital. The most dominant factor with the incidence of MDR TB was result of TB treatment.

Alamat korespondensi: Gedung F5 Lantai 2 FIK Unnes 


\section{PENDAHULUAN}

Tuberkulosis Multi Drug Resistant (TB MDR) adalah jenis TB resisten terhadap dua obat anti tuberkulosis yang paling efektif yaitu Rifampisin dan Isoniazid. Lama pengobatan TB MDR yang dianjurkan ditentukan oleh konversi dahak dan kultur. Anjuran minimal adalah pengobatan harus berlangsung sekurangkurangnya 18 bulan setelah konversi kultur sampai ada bukti-bukti lain untuk memperpendek lama pengobatan (Nawas, 2010). Tuberkulosis Multi Drug Resistant merupakan permasalahan utama di dunia. Pada tahun 2014, terjadi peningkatan pasien TB yang melakukan uji resistensi obat. Tercatat di seluruh dunia, $58 \%$ dari penderita yang telah mengalami pengobatan sebelumnya dan $12 \%$ dari kasus baru diuji, meningkat dari $17 \%$ dan $8,5 \%$ masing-masing pada tahun 2013 . Peningkatan tersebut adalah bentuk adopsi cepat tes molekul yang dilakukan. Jika semua penemuan kasus TB tahun 2014 telah diuji untuk resistensi obat, diperkirakan mencapai 300.000 kasus akan ditemukan memiliki MDR TB. Total 111.000 orang memulai pengobatan MDR TB pada tahun 2014, meningkat sebesar 14\% dibandingkan dengan tahun 2013. Secara global, hanya sebesar 50\% dari pasien MDR TB sukses melakukan pengobatan, namun untuk angka keberhasilan pengobatan MDR TB pada tahun 2015 telah mencapai target yaitu $\geq 75 \%$ oleh 43 dari 127 negara. Tuberkulosis resisten obat secara ekstensif (XDR-TB) telah dilaporkan sebanyak 105 negara pada tahun 2015. Perkiraan 9,7\% dari orang dengan MDR TB memiliki XDR-TB (WHO, 2015).

Pada tahun 2014 terdapat 9,6 juta orang di dunia menderita tuberkulosis. Sebanyak 1,5 juta penderita meninggal akibat tuberkulosis diantaranya 1,1 juta negatif menderita Human Immunodeficiency virus (HIV) dan 0,4 juta positif HIV. 1 dari 3 penderita HIV meninggal akibat tuberkulosis. Pada tahun 2015 lebih dari 70 juta orang di dunia terinfeksi virus HIV, 35 juta orang diantaranya meninggal karena HIV. Secara global 36,7 juta orang hidup dengan HIV dengan prevalensi $0,8 \%$ diderita pada rentang usia antara 15-49 tahun. Prevalensi HIV di Asia Tenggara $(0,3 \%)$ berada pada urutan ke tiga setelah Amerika (0,5\%) dan Afrika (4,4\%) (Romadhoni, 2017). Peningkatan prevalensi TB MDR ini akan meningkat seandainya keberhasilan program pengendalian TB tidak optimal dan prevalensi infeksi oleh HIV terus meningkat (Sjahrurachman, 2010).

Indonesia menduduki rangking ke 8 dari 27 negara-negara yang mempunyai beban tinggi dan prioritas kegiatan untuk TB MDR/XDR. Beban TB MDR di 27 negara ini menyumbang $85 \%$ dari beban TB MDR global (Kemenkes RI, 2014). Ada beberapa faktor penyebab kasus TB MDR terus meningkat, antara lain fasilitas pelayanan pengobatan TB belum merata di 34 provinsi, belum tersedia dan meratanya Rumah Sakit yang melayani rujukan kasus TB MDR, serta belum semua Rumah Sakit melaksanakan program Directly Observed Treatment Short-course (DOTS) yang bagus. Kasus TB MDR terjadi karena rendahnya kepatuhan minum obat yang sering disebabkan adanya efek samping obat jika dilihat dari sisi pasien (Kemenkes RI, 2014).

Rumah Sakit Umum Pusat Dr. Kariadi menjadi rujukan untuk penanganan kasus $\mathrm{TB}$ MDR di Kota Semarang. Total kasus TB MDR dari tahun 2013 hingga bulan Januari 2016 sebanyak 65 kasus. Insiden kasus tahun 2014 dan 2015 menunjukkan angka yang sama yaitu sebesar $32,3 \%$ dari jumlah kasus yang ada, dikaitkan dengan proporsi kejadian TB MDR pada kasus TB baru dan TB kambuh di tahun 2015, terdapat 31 kasus baru TB MDR (Dinkes Kota Semarang, 2016).

Kasus Tuberkulosis di RSUP Dr. Kariadi tiap tahun menunjukkan adanya kenaikan pada pasien rawat inap maupun rawat jalan. Jumlah total pasien rawat inap Tuberkulosis sebanyak 1.621 kasus, sedangkan pada pasien rawat jalan tercatat mencapai 8.845 terhitung hingga Mei tahun 2017. Tuberkulosis MDR di RSUP Dr. Kariadi hingga Mei tahun 2017 sebanyak 2.061 untuk pasien rawat jalan. Tahun 2014 jumlah TB MDR sebanyak 688 kasus, di tahun 2015 terjadi kenaikan hingga mendekati dua kali kasus pada tahun sebelumnya yaitu 1.183 kasus, pada tahun 2016 terjadi kenaikan dari jumlah 
sebelumnya hingga mencapai 1.442 kasus, sedangkan pada Mei tahun 2017 terhitung hingga 2.061 kasus TB MDR.

Sebaran responden penelitian yang bertempat tinggal di Semarang mencakup daerah Kota Semarang sebanyak 90 orang dan Kabupaten Semarang terdapat 1 orang, yaitu di Kecamatan Bandungan. Karakteristik responden di luar Semarang dengan responden terbanyak terdapat di Kabupaten Demak sejumlah 10 orang, kemudian Kabupaten Tegal jumlah 9 orang, dan Kabupaten Kudus sejumlah 8 orang, Kabupaten Pekalongan dan Jepara masing-masing sejumlah 5 orang, Kabupaten Pati sejumlah 4 orang, Kabupaten Batang sejumlah 3 orang, Kabupaten Purworejo 2 orang, serta daerah lain (Brebes, Pemalang, Kendal, Boyolali, Grobogan, Klaten, dan Sleman) masing-masing sejumlah 1 orang.

Data responden dengan kriteria pasien TB MDR yang ditemukan pada sampel penelitian ini dapat dilihat sebarannya, yaitu responden dengan jumlah terbanyak terdapat pada pasien TB kasus kambuh (relaps) kategori I sejumlah 36 orang $(25 \%)$, pasien $\mathrm{TB}$ yang kembali setelah loss to follow-up sejumlah 29 orang $(20,15 \%)$, pasien TB pengobatan kategori I yang gagal sejumlah 24 orang $(16,67 \%)$, pasien ko-infeksi TB-HIV yang tidak respon terhadap pemberian Obat Anti Tuberkulosis (OAT) sejumlah 22 orang $(15,27 \%)$, terduga TB yang mempunyai riwayat kontak dengan pasien $\mathrm{TB}$ MDR sejumlah 21 orang $(14,58 \%)$, pasien $\mathrm{TB}$ pengobatan kategori yang tetap positif setelah 3 bulan pengobatan sejumlah 9 orang $(6,25 \%)$, dan pasien TB kasus kambuh (relaps) kategori II sejumlah 3 orang $(2,08 \%)$.

Mulisa (2015) menyatakan bahwa tidak terdapat hubungan yang signifikan antara usia dengan kejaidan TB MDR $(p=0,24)$. Hasil berbeda ditemukan pada penelitian Workicho (2017), yang menyatakan bahwa pada penelitian yang dilakukan di salah satu rumah sakit di London, kasus TB MDR ditemukan pada pasien berusia lebih muda yang sensitif terhadap obat, dan menunjukkan adanya hubungan antara usia muda dan TB MDR (Adjusted $\mathrm{OR}=1,83 ; 95 \% \mathrm{CI}=1,02-1,05 ; \mathrm{p}=0,001)$.
Jenis kelamin terbanyak perempuan, baik dari kelompok kontrol maupun kelompok kasus. Sebanyak 16 responden atau 59,26\% dari kelompok kontrol berjenis kelamin wanita dan sisanya 11 responden sebesar 40,74\% laki-laki. Sedangkan pada 27 responden kelompok kasus terdapat 12 responden $44,44 \%$ laki-laki dan 15 responden 55,56\% wanita (Mulyanto, 2014). Hal ini berbeda dengan penelitian Munawwarah (2013) yang menyebutkan bahwa TB MDR terbanyak adalah jenis kelamin laki-laki yaitu sebanyak 10 orang atau $60,9 \%$. Studi lain oleh Marahatta (2010) menyatakan bahwa TB MDR terbanyak ditemukan pada jenis kelamin lakilaki dibandingkan perempuan, baik pada kelompok kasus maupun kontrol di dalam penelitian tersebut.

Pada penelitian Ahmad (2012), menyatakan bahwa reponden dengan tingkat pendidikan rendah mempunyai hubungan signifikan dengan kejadian TB MDR (AOR= $5,5 ; \quad 95 \% \mathrm{CI}=1,7-17,6)$. Studi lain yang dikemukakan oleh Mulyanto (2014), menyatakan bahwa tingkat pendidikan pada kelompok kasus maupun kelompok kontrol hampir sama yaitu rata-rata berpendidikan rendah dan sedang $(p=0,79)$, hal ini menunjukan bahwa tidak terdapat hubungan bermakna antara tingkat pendidikan dengan TB MDR ini dikarenakan tidak selamanya penderita yang berpendidikan rendah tingkat pengetahuan mengenai penyakit TB MDR rendah, dan tidak semua yang berpendidikan menengah ke atas memiliki pengetahuan tentang TB MDR tinggi. Saat ini sudah banyak media elektronik, media cetak dan leaflet di sarana pelayanan kesehatan memberikan informasi kepada responden.

Mulisa (2015), menyatakan bahwa tingkat pengetahuan memiliki pengaruh terhadap kejadian TB MDR. Hal ini sejalan dengan penelitian yang dikemukakan Rahayu (2015) tentang tingkat pendidikan relatif rendah menjadikan orang hanya tamat sekolah dasar dan tidak mendapatkan pengetahuan tentang penyakit TB. Pendidikan yang buruk akan menyebabkan masyarakat malu dan muncul sikap untuk menyembunyikan penyakit mereka. 
Kondisi seperti pada beberapa orang dapat menyebabkan penundaan akan penggunaan layanan kesehatan.

Penelitian Mulisa (2015) menyebutkan bahwa terdapat risiko riwayat infeksi HIV dengan kasus TB MDR $(\mathrm{OR}=1,95 \% \mathrm{CI}=1,03$ 6,71 ). Hasil berbeda ditemukan pada penelitian Elmi (2015) yang menyatakan bahwa infeksi HIV adalah prediktor bermakna untuk infeksi TB MDR, pasien yang terinfeksi HIV 78\% lebih kecil kemungkinannya memiliki TB MDR dibandingkan dengan pasien HIV-seronegatif (AOR $=0,22 ; 95 \% \mathrm{CI}=0,08-0,61 ; \mathrm{p}=0,001$ ).

Penelitian Ahmad (2012) yang menunjukkan bahwa proporsi kasus yang lebih tinggi yaitu $52 \%$ dibandingkan dengan kontrol sebesar $27 \%$ responden, pada variabel pendapatan bulanan kurang dari 4000 rupee, sangat penting bagi pasien TB untuk berhasil menyelesaikan pengobatan. Hal ini sejalan dengan penelitian Aderita (2016) yaitu pendapatan keluarga selama sebulan pada kelompok kasus dan kontrol lebih banyak yang memiliki penghasilan $<1.500 .000 /$ bulan yaitu sebesar $88,3 \%$ merupakan kasus dan $75 \%$ untuk kontrol.

Penelitian Fauziah dan Sudaryo (2013) yang menyatakan bahwa penderita TB MDR lebih banyak pada responden yang tidak patuh dalam pengobatan dibandingkan dengan yang patuh. Pasien yang tidak patuh memiliki peluang 10,8 kali untuk mengalami TB MDR dibandingkan dengan pasien yang patuh dengan pengobatannya. Penelitian Rahayu (2015) menyatakan bahwa terdapat hubungan antara peran aktif PMO dengan kejadian TB MDR ( $\mathrm{p}=$ $0,01 ; \mathrm{OR}=5,260 ; 95 \% \mathrm{CI}=2,043-15,359)$.

Riwayat pengobatan TB gagal dan putus berobat merupakan faktor terjadinya TB MDR. Pada penelitian Maharatta (2010) riwayat pengobatan TB berhubungan kuat dengan kejadian MDR TB yaitu dengan diperoleh $\mathrm{OR}=$ $2,799(95 \% \mathrm{CI}=1,159$ hingga 6,667$)(\mathrm{p}=0,020)$. Hal ini sejalan dengan yang dikemukakan oleh Aderita (2016) yaitu kelompok kasus, memiliki riwayat pengobatan tuberkulosis gagal atau putus berobat sebelumnya lebih dominan yaitu $73,3 \%$ terjadi TB MDR.
Ada beberapa faktor yang memiliki hubungan dengan kejadian tuberkulosis multi drug resistant. Berdasarkan uraian tersebut, tujuan penelitian ini yaitu meneliti tentang faktor yang mempengaruhi kejadian tuberkulosis multi drug resistant di RSUP Dr. Kariadi Kota Semarang.

\section{METODE}

Jenis penelitian ini adalah penelitian observasional dengan menggunakan studi analitik. Rancangan penelitian yang digunakan yaitu case control. Penelitian dilaksanakan pada bulan September - November 2017 di RSUP. Dr. Kariadi Kota Semarang.

Besar sampel minimal yang didapat berdasarkan rumus perhitungan sampel minimal dari hasil penelitian Workicho (2017) dengan OR 3,73, p1 0,73, p2 0,42 mengahasilkan sejumlah 65 responden, kemudian ditambahkan spare $10 \%$ sehingga besar sampel penelitian ini adalah 72 orang. Pengambilan sampel untuk kasus dan kontrol menggunakan perbandingan $1: 1$, sehingga besar sampel penelitian ini adalah 72 sampel kasus dan 72 sampel kontrol. Jadi, jumlah sampel secara keseluruhan sebesar 144 sampel. Pengambilan sampel dilakukan dengan teknik non probability samping yaitu purposive sampling dengan kriteria inklusi dan eksklusi.

Sampel kasus dalam penelitian ini adalah pasien TB MDR di RSUP Dr. Kariadi Kota Semarang dalam kurun waktu Januari 2015 hingga Mei 2017 dengan kriteria inklusi tercatat sebagai pasien TB MDR dalam catatan medis RSUP Dr. Kariadi Kota Semarang yaitu mulai Januari 2015 sampai dengan Mei 2017 dan pasien TB MDR berumur $\geq 15$ tahun serta masih menjalani pengobatan di RSUP Dr. Kariadi Kota Semarang. Kriteria eksklusi dari sampel kasus yaitu pasien TB MDR yang meninggal dunia atau pasien tidak bersedia menjadi responden. Sampel kontrol dalam penelitian ini adalah pasien TB terduga MDR tetapi bukan MDR dan telah melakukan tes uji kepekaan OAT dengan hasil tidak resisten pada jenis OAT rifampisin dan isoniazid secara bersamaan, serta tercatat dalam catatan medis 
di RSUP Dr. Kariadi Kota Semarang yaitu mulai Januari 2015 sampai dengan Mei 2017; pasien berumur $\geq 15$ tahun dan masih menjalani pengobatan di RSUP Dr. Kariadi Kota Semarang; dan alamat responden dapat ditemukan. Kriteria eksklusi dari sampel kontrol yaitu pasien TB yang meninggal dunia dan alamat pasien yang berpindah tempat tinggal di luar Kota Semarang.

Sumber data yang digunakan dalam penelitian ini diperoleh dari data primer berupa wawancara secara langsung kepada responden yaitu pasien TB MDR di RSUP Dr. Kariadi Kota Semarang dan data sekunder meliputi data kasus TB MDR di Indonesia, data TB MDR di Provinsi Jawa Tengah, dan data TB MDR di RSUP Dr. Kariadi Kota Semarang yang selanjutnya diolah untuk menjadi informasi yang dibutuhkan.

Instrumen penelitian menggunakan kuesioner dan catatan medis. Teknik pengambilan data dilakukan dengan wawancara menggunakan kuesioner, yaitu pengumpulan data berupa daftar pertanyaan tertulis yang diajukan kepada responden untuk mengetahui variabel berupa riwayat hasil pengobatan $\mathrm{TB}$ sebelumnya, riwayat kepatuhan minum obat, dan peran aktif Pengawas Menelan Obat. Uji validitas dan reabilitas dilakukan untuk mengetahui apakah instrumen yang akan digunakan untuk penelitian sudah valid dan reliabel. Peneliti melakukan uji validitas dan reabilitas kuesioner di RSUD Dr. Moewardi Solo, hal ini dikarenakan Rumah Sakit tersebut memiliki karakteristik yang sama dengan RSUP Dr. Kariadi Kota Semarang. Uji validitas dan reliabilitas dilakukan kepada responden dengan diminta untuk menjawab pertanyaanpertanyaan yang ada dalam bentuk kuesioner.

Proses analisis data dilakukan dengan menggunakan program analisis data yang tersedia dalam aplikasi komputer untuk mengolah data dengan yang bersifat univariat dan bivariat. Analisis univariat disajikan dalam bentuk tabel dan deskriptif. Pada penelitian ini, seluruh variabel memiliki skala kategorik maka penyajian analisis deskriptifnya menggunakan tabel frekuensi dan persentase. Sedangkan
Analisis bivariat dilakukan untuk mengetahui ada atau tidaknya hubungan antara variabel bebas dengan variabel terikat. Uji statistik yang digunakan adalah chi square karena dapat digunakan untuk menganalisis semua variabel yang diteliti. Analisis bivariat dilakukan dengan uji chi square yang digunakan untuk menguji hipotesis hubungan yang signifikan. Dasar pengambilan keputusan penerimaan hipotesis penelitian berdasarkan tingkat signifikansi (nilai $\mathrm{p}$ ), jika nilai $\mathrm{p}>0,05$ maka $\mathrm{H}_{0}$ diterima $\mathrm{H}_{\mathrm{a}}$ ditolak, dan jika $\mathrm{p}<0,05$ maka $\mathrm{H}_{0}$ ditolak $\mathrm{H}_{\mathrm{a}}$ diterima.

\section{HASIL DAN PEMBAHASAN}

Rumah Sakit Umum Pusat Dr. Kariadi menjadi rujukan untuk penanganan kasus TB MDR di Kota Semarang. Tuberkulosis MDR di RSUP Dr. Kariadi dari Januari 2014 hingga Mei tahun 2017 sebanyak 2.061. Tahun 2014 jumlah TB MDR sebanyak 688 kasus, di tahun 2015 terjadi kenaikan hingga mendekati dua kali kasus pada tahun sebelumnya yaitu 1.183 kasus, pada tahun 2016 terjadi kenaikan dari jumlah sebelumnya hingga mencapai 1.442 kasus. Peneliti tertarik melakukan penelitian pada RSUP Dr. Kariadi yang ada di Kota Semarang dengan responden penelitian pasien pada Poliklinik TB MDR sebanyak 144 orang dilakukan selama bulan September-November 2017. Pengumpulan data dalam penelitian ini menggunakan kuesioner yang berisi pertanyaan terkait faktor yang berhubungan dengan kejadian Tuberkulosis Multi Drug Resistant.

Karakteristik responden yang diamati dalam penelitian ini berdasarkan asal daerah pasien dan kriteria pasien TB MDR. Karakteristik responden berdasarkan asal daerah responden dapat dilihat pada tabel 1 .

Berdasarkan tabel 1 diketahui bahwa karakteristik responden paling banyak dari daerah semarang yaitu sejumlah 91 orang $(63,2 \%)$, sedangkan responden yang bertempat tinggal di luar semarang terdapat sejumlah 53 orang $(36,8 \%)$.

Sebaran responden yang bertempat tinggal di Semarang mencakup daerah Kota 
Tabel 1. Karakteristik Responden Berdasarkan Asal Daerah

\begin{tabular}{lcc}
\hline \multirow{2}{*}{ Asal Daerah } & \multicolumn{2}{c}{ Frekuensi } \\
\cline { 2 - 3 } & $\mathrm{n}$ & \% \\
\hline Semarang & 91 & 63,2 \\
Luar Semarang & & \\
& 53 & 36,8 \\
\hline Jumlah & 144 & 100 \\
\hline
\end{tabular}

Semarang sebanyak 90 orang dan Kabupaten Semarang terdapat 1 orang, yaitu di Kecamatan Bandungan. Karakteristik responden di luar Semarang dengan responden terbanyak terdapat di Kabupaten Demak sejumlah 10 orang, kemudian Kabupaten Tegal jumlah 9 orang, dan Kabupaten Kudus sejumlah 8 orang, Kabupaten Pekalongan dan Jepara masingmasing sejumlah 5 orang, Kabupaten Pati sejumlah 4 orang, Kabupaten Batang sejumlah 3 orang, Kabupaten Purworejo 2 orang, serta daerah lain (Brebes, Pemalang, Kendal, Boyolali, Grobogan, Klaten, dan Sleman) masing-masing sejumlah 1 orang.

Data responden dengan karakteristik responden berdasarkan kriteria pasien TB MDR yang ditemukan pada sampel penelitian ini dapat dilihat sebarannya, yaitu responden dengan jumlah terbanyak terdapat pada pasien TB kasus kambuh (relaps) kategori I sejumlah 36 orang (25\%), pasien TB yang kembali setelah loss to follow-up sejumlah 29 orang (20,15\%), pasien TB pengobatan kategori I yang gagal sejumlah 24 orang $(16,67 \%)$, pasien ko-infeksi TB-HIV yang tidak respon terhadap pemberian OAT sejumlah 22 orang $(15,27 \%)$, terduga $\mathrm{TB}$ yang mempunyai riwayat kontak dengan pasien TB MDR sejumlah 21 orang (14,58\%), pasien TB pengobatan kategori yang tetap positif setelah 3 bulan pengobatan sejumlah 9 orang $(6,25 \%)$, dan pasien TB kasus kambuh (relaps) kategori II sejumlah 3 orang (2,08\%). Menurut Hardiarto (1999) dalam Sianturi (2014) TB setelah pengobatan dapat disebabkan oleh kekambuhan infeksi dengan strain yang sama. Bahaya resistensi obat bila terjadi MDR, penyakit tersebut dapat kembali dengan lebih kuat, lebih sulit diobati dan pengobatannya sangat mahal, keberhasilannya rendah.
Data primer diperoleh dengan menggunakan instrumen berupa kuesioner yang dilakukan pada bulan September-November di Poliklinik TB MDR, Puskesmas, dan rumah responden. Bagian pertama merupakan data primer hasil analisis univariat berupa distribusi dan frekuensi variabel terikat (kejadian TB MDR) dan variabel bebas (riwayat peran aktif Pengawas Menelan Obat, riwayat hasil pengobatan TB sebelumnya, dan riwayat kepatuhan minum obat). Pada bagian terakhir, akan dibahas mengenai hasil analisis bivariat berupa hubungan antar variabel penelitian (variabel bebas dan variabel terikat).

Berdasarkan tabel 2 pada analisis univariat menunjukkan bahwa distribusi responden TB MDR paling banyak dari kelompok berusia produktif yaitu sebanyak 100 orang $(69,4 \%)$, sedangkan usia tidak produktif ditemukan sebanyak 44 orang $(30,6 \%)$. Responden dengan jenis kelamin laki-laki sebanyak 65 orang $(45,1 \%)$, sedangkan perempuan sejumlah 79 orang $(54,9 \%)$ merupakan kelompok dengan distribusi paling banyak. Kelompok responden memiliki tingkat pendidikan rendah sebanyak 71 orang $(49,3 \%)$, sedangkan data paling banyak pada kelompok responden dengan pendidikan tinggi sebanyak 72 orang $(50,7 \%)$ dengan perbedaan jumlah tidak terlalu jauh. responden dengan pendapatan rendah sebanyak 78 orang $(54,2 \%)$ adalah kelompok dengan distribusi responden paling banyak, sedangkan responden yang memiliki pendapatan tinggi sebanyak 66 orang (45,8\%). Sebanyak 45 orang (31,2\%) PMO tidak berperan aktif dalam pengobatan TB, sedangkan data terbanyak dapat dilihat pada kelompok dengan PMO yang berperan aktif dalam pengobatannya sebanyak 99 responden $(68,8 \%)$. Kelompok responden yang memiliki kepatuhan buruk sebanyak 41 orang $(28,5)$, sedangkan data dengan jumlah distribusi paling banyak yaitu pada responden mempunyai riwayat kepatuhan minum obat baik sejumlah 103 responden (71,5\%). Responden dengan riwayat hasil pengobatan TB sebelumnya gagal sebanyak 41 orang $(28,5 \%)$, sedangkan responden dengan riwayat hasil pengobatan sembuh sebanyak 46 
Tabel 2. Hasil Analisis Univariat Distribusi Responden Menurut pada Variabel Penelitian

\begin{tabular}{lcc}
\hline \multicolumn{1}{c}{ Variabel } & \multicolumn{2}{c}{ Frekuensi } \\
& $\mathrm{n}$ & $\%$ \\
\hline usia Produktif & 100 & 69,4 \\
Tidak Produktif & 44 & 30,6 \\
Total & 144 & 100 \\
\hline Jenis Kelamin & & \\
\hline Laki-laki & 65 & 45,1 \\
Perempuan & 79 & 54,9 \\
Total & 144 & 100 \\
\hline Tingkat Pendidikan & & \\
\hline Rendah & 71 & 49,3 \\
Tinggi & 73 & 50,7 \\
Total & 144 & 100 \\
\hline Pendapatan & & \\
\hline Rendah & 78 & 54,2 \\
Tinggi & 66 & 45,8 \\
Total & 144 & 100 \\
\hline Peran Aktif PMO & & \\
\hline Tidak Aktif & 45 & 31,2 \\
Aktif & 99 & 68,8 \\
Total & 144 & 100 \\
\hline Riwayat Kepatuhan Minum Obat \\
\hline Buruk \\
Baik & 41 & 28,5 \\
Total & 103 & 71,5 \\
\hline Riwayat Hasil Pengobatan & 144 & 100 \\
\hline Gagal Sebelumnya \\
Putus Berobat & 41 & 28,5 \\
Tidak dievaluasi & 34 & 23,6 \\
Sembuh & 23 & 16,0 \\
Total & 46 & 31,9 \\
\hline Kejadian TB MDR & 144 & 100 \\
\hline Kasus & 72 & \\
Kontrol & 72 & 50 \\
Total & 144 & 100 \\
\hline & & \\
\hline & & \\
\hline
\end{tabular}

orang $(31,9 \%)$ merupakan kelompok data dengan jumlah distribusi paling banyak.

Berdasarkan hasil penelitian tabel 3 menunjukkan bahwa variabel usia memiliki $\mathrm{p}$ value sebesar $0,047<\alpha(0,05)$ yang artinya ada hubungan antara usia dengan kejadian $\mathrm{TB}$ MDR. Penelitian ini sejalan dengan Workicho (2017), yang menyatakan bahwa pada penelitian yang dilakukan di salah satu rumah sakit di London, kasus TB MDR ditemukan pada pasien berusia lebih muda yang sensitif terhadap obat, dan menunjukkan adanya hubungan antara usia muda dan TB MDR (AOR = 1,83; $95 \% \mathrm{CI}=1,02-1,05 ; \mathrm{p}=0,001)$. Studi lain oleh Maharjan (2017), menunjukkan bahwa usia tidak mempunyai hubungan dengan kejadian TB MDR (AOR = 0,649; 95\%CI=0.166-2.532; $p=0,53)$. Hasil sama juga ditemukan pada penelitian Chuchottaworn (2015), yang menyatakan bahwa tidak ada hubungan signifikan antara usia dengan TB MDR $(\mathrm{OR}=0.87 ; 95 \% \mathrm{CI}=0.55-1.38 ; \mathrm{p}=0,636)$.

Penelitian Ahmad (2012), menyebutkan bahwa laki-laki dianggap relatif tidak peduli daripada wanita terkait asupan OAT secara teratur, dan fakta ini mungkin menyebabkan lebih banyak laki-laki yang menderita TB MDR. Hal ini sejalan dengan penelitian Maharatta (2010) yang menyatakan bahwa TB MDR terbanyak ditemukan pada jenis kelamin lakilaki dibandingkan perempuan, baik pada kelompok kasus maupun kontrol di dalam penelitian tersebut. Berdasarkan hasil perhitungan menggunakan uji chi square diperoleh $\mathrm{p}$ value sebesar $0,617>\alpha(0,05)$, yang artinya tidak ada hubungan antara jenis kelamin dengan kejadian TB MDR. Pada penelitian ini, sebanyak 50\% antara responden kelompok lakilaki dan perempuan mempunyai peluang sama untuk sakit TB MDR. Penelitian ini sejalan dengan Mulisa (2015), yang menjelaskan bahwa tidak ada hubungan antara jenis kelamin dengan kejadian TB MDR dibuktikan dengan nilai $p=0,76$. Penelitian Fauziah dan Sudaryo (2013), menyatakan bahwa tidak terdapat hubungan signifikan antara jenis kelamin dengan kejadian TB MDR yang dibuktikan dengan $\mathrm{p}$ value sebesar 0,385 .

Hasil penelitian berbeda ditemukan pada Maharjan (2017) yang menyatakan bahwa jenis kelamin mempunyai hubungan yang signifikan dengan kejadian TB MDR $(\mathrm{OR}=9,237$; 95\%CI $=1,032-82,705 ; p=0,05)$. Penelitian Workicho (2017) menyatakan bahwa tingkat pendidikan rendah memiliki risiko untuk kejadian TB MDR (OR=0,43; 95\%CI $=0,19$ 1,95). Hasil berbeda ditemukan pada penelitian Hirpa (2013), yaitu pendidikan tinggi lebih 
Tabel 3. Hasil Analisis Bivariat (Hubungan Variabel Bebas dengan Kejadian TB MDR di RSUP. Dr. Kariadi Kota Semarang)

\begin{tabular}{|c|c|c|c|c|c|c|c|c|}
\hline \multirow{2}{*}{ Variabel } & \multicolumn{2}{|c|}{ Kasus } & \multicolumn{2}{|c|}{ Kontrol } & \multicolumn{2}{|c|}{ Total } & \multirow[b]{2}{*}{$p$ value } & \multirow[b]{2}{*}{ OR $(95 \% \mathrm{CI})$} \\
\hline & $\mathrm{n}$ & $\%$ & $\mathrm{n}$ & $\%$ & $\mathrm{n}$ & $\%$ & & \\
\hline \multicolumn{9}{|l|}{ Usia } \\
\hline Produktif & 56 & 77,8 & 44 & 61,1 & 100 & 69,4 & \multirow{3}{*}{0,047} & \multirow{4}{*}{$\begin{array}{c}2,227(1,072- \\
4,623)\end{array}$} \\
\hline Tidak Produkti & 16 & 22,2 & 28 & 38,9 & 44 & 30,6 & & \\
\hline Total & 72 & 100 & 72 & 100 & 144 & 100 & & \\
\hline \multicolumn{8}{|l|}{ Jenis Kelamin } & \\
\hline Laki-laki & 36 & 50 & 32 & 44,4 & 115 & 47,2 & \multirow{3}{*}{0,617} & \multirow{3}{*}{$\begin{array}{l}1,250(0,649- \\
2.407)\end{array}$} \\
\hline Perempuan & 36 & 50 & 40 & 55,6 & 29 & 55,6 & & \\
\hline Total & 72 & 100 & 72 & 100 & 144 & 100 & & \\
\hline \multicolumn{9}{|c|}{ Tingkat Pendidikan } \\
\hline Rendah & 39 & 54,2 & 32 & 44,4 & 71 & 49,3 & \multirow{3}{*}{0,317} & \multirow{3}{*}{$\begin{array}{c}1,477(0,766- \\
2.848)\end{array}$} \\
\hline Tinggi & 33 & 45,8 & 40 & 55,6 & 73 & 50,7 & & \\
\hline Total & 72 & 100 & 72 & 100 & 144 & 100 & & \\
\hline \multicolumn{9}{|l|}{ Pendapatan } \\
\hline Rendah & 46 & 63,9 & 32 & 44,4 & 78 & 54,2 & \multirow{3}{*}{0,030} & \multirow{3}{*}{$\begin{array}{l}2,212(1,133- \\
\quad 4.317\end{array}$} \\
\hline Tinggi & 26 & 36,1 & 40 & 55,6 & 66 & 45,8 & & \\
\hline Total & 72 & 100 & 72 & 100 & 144 & 100 & & \\
\hline \multicolumn{9}{|l|}{ Peran Aktif PMO } \\
\hline Tidak Aktif & 29 & 40,3 & 16 & 22,2 & 45 & 31,2 & \multirow{5}{*}{0,031} & \multirow{3}{*}{$\begin{array}{c}5,636(2,233- \\
4,227)\end{array}$} \\
\hline Aktif & 43 & 59,7 & 56 & 77,8 & 99 & 68,8 & & \\
\hline Total & 72 & 100 & 72 & 100 & 144 & 100 & & \\
\hline \multirow{2}{*}{\multicolumn{8}{|c|}{$\begin{array}{l}\text { Riwayat Kepatuhan } \\
\text { Minum Obat }\end{array}$}} & \\
\hline Minum Obat & & & & & & & & \\
\hline Buruk & 27 & 37,5 & 14 & 19,4 & 41 & 28,5 & \multirow{3}{*}{0,027} & \multirow{3}{*}{$\begin{array}{c}3,338(1,322- \\
8,432)\end{array}$} \\
\hline Baik & 45 & 62,5 & 58 & 80,6 & 103 & 71,5 & & \\
\hline Total & 72 & 100 & 72 & 100 & 144 & 100 & & \\
\hline \multicolumn{9}{|c|}{$\begin{array}{c}\text { Riwayat Hasil Pengobatan } \\
\text { TB Sebelumnya }\end{array}$} \\
\hline Gagal & 30 & 41,7 & 11 & 15,3 & 41 & 28,5 & \multirow{5}{*}{$<0,001$} & $\begin{array}{c}5,636(2,233- \\
14,227)\end{array}$ \\
\hline Putus Berobat & 21 & 29,2 & 13 & 18,1 & 34 & 23,6 & & $\begin{array}{l}3,338(1,322- \\
8,432)\end{array}$ \\
\hline Tidak dievaluasi & 6 & 8,3 & 17 & 23,6 & 23 & 16,0 & & $\begin{array}{c}0,729(0,239- \\
2,227)\end{array}$ \\
\hline Sembuh & 15 & 20,8 & 31 & 43,1 & 46 & 31,9 & & 1 \\
\hline Total & 72 & 100 & 72 & 100 & 144 & 100 & & \\
\hline
\end{tabular}

berisiko untuk sakit TB MDR 3,7 kali dibandingkan dengan seseorang yang memiliki pendidikan rendah $(\mathrm{OR}=3,7 ; 95 \% \mathrm{CI}=1,1-$ 12,1). Berdasarkan hasil penelitian menunjukkan bahwa variabel tingkat pendidikan memiliki interval kepercayaan $0,766-2,848$ (mencakup angka 1 ) dan $\mathrm{p}$ value sebesar $0,617>\alpha(0,05)$, yang artinya tidak ada hubungan antara tingkat pendidikan dengan kejadian TB MDR. Penelitian ini sejalan dengan Mulisa (2015) yang menyatakan bahwa tidak adanya riwayat pendidikan memiliki risiko untuk menyebabkan sakit TB MDR $(\mathrm{OR}=0,8$; $95 \% \mathrm{CI}=0,10-6,24)$.
Keluarga yang mempunyai pendapatan di bawah Upah Minimum Regional (UMR) akan mengkonsumsi makanan dengan kadar gizi yang tidak mencukupi kebutuhan bagi setiap anggota keluarga sehingga mempunyai status gizi yang kurang dan akan menjadikan risiko terkena penyakit infeksi TB MDR (Aderita, 2016). Pada penelitian Ahmad (2012) menyebutkan bahwa pendapatan rendah berisiko 3 kali untuk kejadian TB MDR (OR= $3,95 \% \mathrm{CI}=1,3-7,1)$. Berdasarkan hasil penelitian menunjukkan bahwa variabel pendapatan memiliki interval kepercayaan 1,133-4.317 (tidak mencakup angka 1) dan $p$ value sebesar 
$0,030<\alpha(0,05)$, yang artinya ada hubungan antara pendapatan dengan kejadian TB MDR. Penelitian ini sejalan dengan pada penelitian Workicho (2017) yang menyebutkan bahwa pendapatan bulanan dengan $\mathrm{OR}=4,5$ dan $95 \% \mathrm{CI}=1,67-12,38$ didapatkan dari pendapatan bulanan tinggi. Hasil berbeda ditemukan pada penelitian Fauziah dan Sudaryo (2013), yang menyatakan bahwa pendapatan tidak mempunyai hubungan dengan kejadian TB MDR, hal ini dibuktikan dengan nilai $\mathrm{p}=0,133$.

Pengawas Menelan Obat adalah salah satu faktor keberhasilan program DOTS (Directly Observed Therapy Short-course) dan keberhasilan terapi karena mempengaruhi kepatuhan minum obat sehingga penderita rajin dan termotivasi untuk meminum obat. Seorang PMO harus dikenal, dipercaya dan disetujui, baik oleh petugas kesehatan, maupun pasien, selain itu harus disegani dan dihormati oleh pasien, seseorang yang tinggal dekat dengan pasien, bersedia membantu pasien dengan sukarela dan bersedia dilatih dan atau mendapat penyuluhan (Kemenkes RI, 2014).

Hasil uji statistik menunjukkan bahwa variabel peran aktif PMO memiliki interval 1,139-4,890 (tidak mencakup angka 1) dan $\mathrm{p}$ value sebesar $0,031<\alpha(0,05)$, yang artinya ada hubungan antara riwayat peran aktif PMO dengan kejadian TB MDR. Pengawas Menelan Obat yang berperan dalam penelitian ini yaitu dari pihak keluarga (istri/suami/anak/menantu/orang tua/sanak saudara). Suami merupakan PMO yang berperan membantu responden dalam pengobatan penelitian TB ini, yaitu sejumlah 38 orang, lalu PMO istri sejumlah 27 orang, PMO orang tua sejumlah 11 orang, serta PMO petugas kesehatan dan sanak saudara masingmasing sejumlah 1 orang. Penelitian ini sejalan dengan yang dikemukakan oleh Rahayu (2015), bahwa terdapat hubungan yang bermakna antara peran aktif PMO dengan kejadian $\mathrm{TB}$ MDR (OR=5,260; 95\% CI=2,043-15,359; $\mathrm{p}=$ 0,001).

Kepatuhan merupakan hal yang penting untuk menghindari terjadinya TB MDR dan kegagalan dalam pengobatan (Aderita, 2016). Hal ini sejalan dengan penelitian Fauziah dan Sudaryo (2013) yang menyatakan bahwa penderita TB MDR lebih banyak pada responden yang tidak patuh dalam pengobatan dibandingkan dengan yang patuh $(\mathrm{OR}=10,3$; $95 \% \mathrm{CI}=4,5-23,8 ; \mathrm{p}=0,005)$. Hasil analisis pada penelitian ini menunjukkan bahwa variabel riwayat kepatuhan minum obat memiliki interval 1,170-5,282 (tidak mencakup angka 1) dan $\mathrm{p}$ value sebesar $0,027<\alpha(0,05)$, yang artinya ada hubungan antara riwayat kepatuhan minum obat dengan kejadian TB MDR. Besar OR adalah 2,486 yang berarti bahwa responden dengan kepatuhan minum obat buruk berisiko 2,486 kali sakit TB MDR dibandingkan responden yang patuh dalam minum OAT pada pengobatan TB. Penelitian ini sejalan dengan Rahayu (2015), yang menyatakan bahwa terdapat hubungan yang bermakna antara kepatuhan minum obat dengan kejadian TB MDR, hal ini dibuktikan dengan nilai $p=0,010$.

Penderita TB MDR biasanya terjadi pada individu yang memiliki riwayat pengobatan TB sebelumnya dibandingkan dengan pasien kasus baru (Kemenkes RI, 2014). Penelitian Hirpa (2013) menunjukkan bahwa memiliki lebih dari satu riwayat pengobatan TB meningkatkan risiko kejadian TB MDR, hal ini terkait dengan hasil pengobatan sebelumnya, yaitu putus berobat, gagal pengobatan, kambuh, atau pasien yang pernah melakukan pengobatan TB MDR.

Riwayat hasil pengobatan TB memiliki interval kepercayaan 2,233-14,227 (tidak mencakup angka 1) dan $p$ value sebesar $<0,001$ $<\alpha(0,05)$, yang artinya ada hubungan antara riwayat hasil pengobatan TB sebelumnya dengan kejadian TB MDR. Besar OR dengan riwayat hasil pengobatan TB gagal adalah 5,636 yang berarti bahwa responden tersebut berisiko 5,636 kali sakit TB MDR dibandingkan responden dengan riwayat hasil pengobatan $\mathrm{TB}$ sebelumnya sembuh. Riwayat hasil pengobatan TB putus berobat memiliki nilai OR sebesar 3,338 yang berarti bahwa responden dengan riwayat hasil pengobatan $\mathrm{TB}$ putus berobat berisiko 3,338 kali sakit TB MDR dibandingkan responden dengan riwayat hasil pengobatan TB 
sebelumnya sembuh. Kelompok dengan riwayat hasil pengobatan tidak dievaluasi tidak memiliki nilai OR sebesar 0,729 yang berarti bahwa responden dengan riwayat hasil pengobatan $\mathrm{TB}$ tidak dievaluasi berisiko 0,729 kali sakit TB MDR dibandingkan responden dengan riwayat hasil pengobatan TB sebelumnya sembuh. Penelitian ini sejalan dengan Mulisa (2015), yang menyebutkan bahwa seseorang dengan hasil pengobatan TB gagal berisiko kasus $\mathrm{TB}$ MDR dengan nilai $\mathrm{OR}=3,5 \quad(95 \% \mathrm{CI}=1,57-$ 6,99).

\section{PENUTUP}

Berdasarkan hasil penelitian, dapat disimpulkan bahwa ada hubungan antara riwayat peran aktif $\mathrm{PMO}$, riwayat kepatuhan minum obat, dan riwayat hasil pengobatan $\mathrm{TB}$ sebelumnya dengan kejadian TB MDR di RSUP. Dr. Kariadi Kota Semarang.

Saran bagi penelitian selanjutnya yaitu pemilihan sampel kasus sebaiknya diambil dari kasus terbaru, begitu juga dengan sampel kontrol dipilih responden yang tidak lebih dari 2 tahun terakhir sejak melakukan tes GeneXpert untuk mengetahui diagnosis TB MDR dikarenakan jika sampel kontrol dipilih lebih dari 2 tahun terakhir maka besar kemungkinan sampel tersebut masuk dalam kasus TB MDR. Penggunaan matching antara kelompok kasus dan kontrol, yaitu dengan mengkategorikan sampel penelitian pada kelompok umur produktif yang memiliki mobilitas tinggi dan berisiko untuk penularan TB MDR. Penelitian lanjutan dengan cara kualitatif disarankan, terutama pada variabel kepatuhan dalam pengobatan Tuberkulosis MDR yang membutuhkan pendekatan dengan melakukan wawancara mendalam untuk mengetahui seberapa besar pengaruh variabel tersebut.

\section{DAFTAR PUSTAKA}

Aderita, N. I., Bhisma, M., Nunuk, S. 2016. Risk Factors Affecting Multi-Drug Resistant Tuberculosis in Surakarta and Ngawi,
Indonesia. Journal of Health Promotion and Behavior, 1(2): 90-103

Ahmad, A. M., Akhtar, S., Hasan, R., Khan, J. A., Hussain, S.F., \& Rizvi, N. 2012. Risk factors for Multi Drug-Resistance tuberculosis in urban Pakistan: A multicenter case-control study. International Journal of Mycobacteriology, 1(8): 137-142

Chuchottaworn, C., Thanachartwet, V., Sangsayunh, P., Than, T. Z. M., Sahassananda, D., Surabotsophon, M., Desakorn, V. 2015. Risk Factors for Multidrug-Resistant Tuberculosis among Patients with Pulmonary Tuberculosis at the Central Chest Institute of Thailand. PLoS ONE, 10 (10)

Dinkes Kota Semarang. 2016. Profil Kesehatan Kota Semarang Tahun 2016. Semarang: Dinkes Kota Semarang

Elmi, O.S., Hasan, H., Abdullah, S., Zuki, M. J. M. Alwi, Z. B., \& Naing, N. N. (2015). Multidrug-resistant tuberculosis and risk factors associated with its development: a retrospective study. Journal Infection Developing Countries, 9(10):1076-1085

Fauziah, L. A. dan Sudaryo, M. K. (2013). Faktorfaktor yang Berpengaruh Terhadap Kejadian Tuberkulosis Multi Drug Resistance (TB MDR) di RSUP Persahabatan Tahun 2013. Skripsi. Jakarta: Fakultas Kesehatan Masyarakat Universitas Indonesia

Gomes, M., Correia, A., Mendoca, D., \& Duarte, R. 2014. Risk Factors for Drug-Resistant Tuberculosis. Journal of Tuberculosis Research, 2(3): 111-118

Hirpa, S., Medhin, G., Girma, B., Melese, M., Mekonen, A., Suarez, P., \& Ameni, G. 2013. Determinants of Multi Drug-Resistance tuberculosis in patients who underwent firstline treatment in Addis Ababa: a case control study. BMC Public Health, 1 (13): 782-791

Kemenkes RI. 2014. Pedoman Nasional Pengendalian Tuberkulosis. Jakarta: Direktorat Jenderal Pengendalian Penyakit dan Penyehatan Lingkungan

Maharatta, S. B., Kaewkungwal, J., Ramasoota, P., \& Singhasivanon, P. 2010. Risk factors of Multi Drug Resistance Tuberculosis in central Nepal: A pilot study. Kathmandu University Medical Journal, 8(3): 392-397

Maharjan, S., Singh, A., Khadka, D. K., \& Aryal, M. 2017. Drug Resistance Pattern in Pulmonary Tuberculosis Patients and Risk Factors Associated with Multi-Drug Resistant 
Tuberculosis. Journal of Tuberculosis Research, 5(2): 106-117

Mulisa, G., Workneh, T., Hordofa, N., Suaudi, M., Abebe, G., \& Jarso, G. 2015. Multi DrugResistance Mycobacterium tuberculosis and associated risk factors in Oromia of Ethiopia. International Journal of Infectious Diseases, 39(5): $57-61$

Mulyanto, H. 2014. Hubungan Lima Indikator Perilaku Hidup Bersih dan Sehat dengan Tuberkulosis Multi Drug Resistance. Jurnal Berkala Epidemiologi, 2(3): 355-367

Munawwarah, R., Leida, I., \& Wahiduddin. 2013. Gambaran Faktor Risiko Pengobatan Pasien TB MDR Rs Labuang Baji Kota Makassar Tahun 2013. Hasanudin Student Journal, 2(5)

Nawas, A., 2010. Penatalaksanaan TB-MDR dan Strategi DOTs Plus. Jurnal Tuberkulosis Indonesia, 7(1):1-7

Rahayu, S. R., Katsuyama, H., Demura, M., Katsuyama, M., Ota, Y., Tanii, H., Higashi, T., Semadi, N. P. D., \& Saijoh, K. 2015. Factors associated with tuberculosis cases in
Semarang District, Indonesia: case-control study performed in the area where case detection rate was extremely low. Environtal Health and Preventive Medicine, 20(4): 253-261

Romadhoni, S., dan Widowati, E. 2017. Penerapan Kewaspadaan Standar Sebagai Upaya Pencegahan Bahaya Biologi Pada Tenaga Keperawatan. HIGEIA, 1(4): 14-24

Sianturi, R. 2014. Analisis Faktor yang Berhubungan dengan Kekambuhan TB Paru (Studi Kasus di BKPM Semarang Tahun 2013). Unnes Journal of Public Health, 3(1): 1-10

Sjahrurachman, A. 2010. Diagnosis Multi Drug Resistance Tuberculosis. Jurnal Tuberkulosis Indonesia, 7(1) :8-10

Workicho, A., Wondwosen K., \& Fessahaye A. 2017. Risk factors for multidrug-resistant tuberculosis among tuberculosis patients: a case-control study. Journal Infection and Drug Resistance, 10(7): 91-96

WHO. 2015. Global Tuberculosis Control WHO Report 2015. France: WHO Press. 